\title{
Antibacterial Activities of Five Medicinal Plants in Ethiopia against Some Human and Animal Pathogens
}

\author{
Gebremedhin Romha ${ }^{D},{ }^{1}$ Birhanu Admasu, ${ }^{2}$ Tsegaye Hiwot Gebrekidan, ${ }^{3}$ \\ Hailelule Aleme $\left(10,{ }^{4}\right.$ and Gebreyohans Gebru ${ }^{5}$ \\ ${ }^{1}$ Department of Animal Production and Technology, College of Agriculture and Environmental Science, \\ Adigrat University, Adigrat, Ethiopia \\ ${ }^{2}$ Department of Animal and Range Science, College of Agriculture and Natural Resources, Dilla University, Dilla, Ethiopia \\ ${ }^{3}$ Department of Chemistry, College of Natural and Computational Science, Dilla University, Dilla, Ethiopia \\ ${ }^{4}$ Department of Animal and Range Science, Dilla University, Dilla, Ethiopia \\ ${ }^{5}$ Department of Animal Sciences, College of Agriculture, Aksum University, Shire Campus, Shire, Ethiopia
}

Correspondence should be addressed to Gebremedhin Romha; gebremedhinromha@yahoo.com

Received 26 August 2017; Revised 13 October 2017; Accepted 14 November 2017; Published 11 January 2018

Academic Editor: Jenny M. Wilkinson

Copyright ( 2018 Gebremedhin Romha et al. This is an open access article distributed under the Creative Commons Attribution License, which permits unrestricted use, distribution, and reproduction in any medium, provided the original work is properly cited.

\begin{abstract}
Objective. To evaluate the in vitro antibacterial activities of five plant extracts which have been used as traditional medicines by local healers against three multidrug resistant bacteria, namely, Staphylococcus aureus, Escherichia coli, and Pseudomonas aeruginosa. Results. The highest mean zone of inhibition $(4.66 \mathrm{~mm})$ was recorded from methanol extract of Calpurnia aurea (Ait.) Benth. at a concentration of $200 \mathrm{mg} / \mathrm{ml}$ against S. aureus, followed by Croton macrostachyus Del. $(4.43 \mathrm{~mm})$ at the same dose and solvent for the same bacterial species, while methanol and chloroform extracts of E. brucei Schwein. did not inhibit growth of any bacterial species. The lowest value $(100 \mu \mathrm{g} / \mathrm{ml})$ of minimum inhibitory concentration (MIC) was observed from both methanol and chloroform extracts of $C$. aurea (Ait.) Benth. against all the three bacteria. The results of the positive control had no statistically significant difference $(P>0.05)$ when compared with crude extracts of $C$. aurea (Ait.) Benth. at concentration of $200 \mathrm{mg} / \mathrm{ml}$ against $S$. aureus. Conclusion. The results of the present study support the traditional uses of these medicinal plants by the local healers. Except Erythrina brucei Schwein., all the plants investigated in this study exhibited antibacterial activities against the test bacterial species. Further researches are needed to be conducted to evaluate efficacy of these medicinal plant species on other microbes in different agroecological settings and their safety levels as well as their phytochemical compositions.
\end{abstract}

\section{Introduction}

Although plenty of guidelines have been developed and set for application to prevent foodborne diseases and food spoiling microorganisms, it is impossible totally to be free of them. S. aureus and E. coli are among the major causes of foodborne diseases [1,2]. Species of Pseudomonas are also predominant causes of food spoilage $[3,4]$. The emergence of drug resistance to multiple antibiotics worsens the problem. Nowadays, reports have indicated that Staphylococcus aureus (S. aureus), Escherichia coli (E. coli), and Pseudomonas aeruginosa (P. aeruginosa) are not only multidrug resistant pathogens [5-7] but also broadly drug-resistant and pandrug-resistant bacteria [8]. For instance, it has been reported worldwide that $S$. aureus isolates are increasingly resistant to a greater number of antimicrobial agents as reviewed in Lowy [5]. Multidrug resistance in E. coli increased from $7.2 \%$ during the $1950 \mathrm{~s}$ to $63.6 \%$ during the $2000 \mathrm{~s}$, and particularly considerable growing trend in resistance was noticed for ampicillin, sulfonamide, and tetracycline [6]. P. aeruginosa has also showed resistance to the most frequently administered antipseudomonal antibiotics: $\beta$-lactams, aminoglycosides, and fluoroquinolones [7]. S. aureus, E. coli, and P. aeruginosa are also responsible for the majority of nosocomial infections [9]. 
Antibiotics that show low efficacy in treating human and animal diseases through antibiotic resistance must be replaced with new drugs to combat the burden of these pathogens [10]. Hence, medicinal plants are expected to be the best source of obtaining a variety of drugs [11, 12]. In Ethiopia, different communities have extensively been using medicinal plants to treat different diseases for many centuries [13-15]. Such plants, however, need to be investigated for better understanding of their properties, safety, and efficiency [16]. Medicinal plants including C. aurea (Ait.) Benth., C. macrostachyus Del., and Withania somnifera (W. somnifera) (L.) Dunal have been tested for their antimicrobial efficacy in vitro and in vivo in different countries [17-25]. Previous information of the current study plants is presented in Table 1. However, testing the efficacy of these plants in different agroecological zones can make the evidence more strong since agroecology (e.g., geographic location and soil type) could affect the accumulation of bioactive pharmaceutical ingredients that are found in plants [26].

As reviewed in Mahidol et al. [27], medicinal plants have been used for treating infectious diseases because of their ease of accessibility as well as their lower side effects and toxicity. Medicinal plants may provide an exceptional renewable resource for the discovery of potential novel pharmaceuticals as their constituents have ample structural and biological diversity [27-29]. In Ethiopia, many plant species are being used as traditional medicine for the treatment of various human and animal diseases [20,30-39]. Hence, more studies related to the use of medicinal plants as remedial agents need to be conducted, especially for plants which are useful to control antibiotic resistant microbes [40]. The aim of this study was to evaluate the efficacy of five plant extracts, which have been used as traditional medicines by local healers for their in vitro antibacterial activities against three multidrug resistant bacteria, namely, S. aureus, E. coli, and P. aeruginosa.

\section{Materials and Methods}

2.1. Preparation of Plant Material and Crude Extracts. Five species of plants (Table 2), which have been widely used by local healers in different areas of southern Ethiopia for the treatment of livestock diseases [39], were collected from different agroecological zones to evaluate their in vitro antibacterial effects. The study was conducted from December 2015 to September 2016 at Dilla University. C. aurea (Ait.) Benth. and W. somnifera (L.) Dunal were collected from Yabello district, Borena zone, Oromia regional state, which is $5-6 \mathrm{~km}$ far from Yabello town. C. macrostachyus Del., and E. brucei Schwein. were collected from Dilla University Campus, Gedeo zone, while N. tabacum L. was collected from Seid Hassen Integrated Farm (private farm), Sidama zone, which is located at around $30 \mathrm{~km}$ west of Dilla town. Plant leaves and roots (for W. somnifera (L.) Dunal) were collected from their natural habitat and washed with tap water to remove unnecessary particles and dried under shade at a room temperature for about a month.

The procedure used for the preparation of the plant materials was adapted from Eloff [46]. Briefly, the dried plant materials were then ground using a commercial blender.
The powders of each plant were weighed using precision standard electronic balance before maceration (Table 2). Maceration of each plant was carried out in flasks containing methanol (99.8\%) and chloroform (95\%) separately in a $1: 10$ (solute: solvents) ratio enough to cover all the plant powders with a continuous shaking with an orbital shaker (Gemmy Industrial Corporation, VRN-480) at $100 \mathrm{rpm}$ and an occasional manual stirring with a glass rod. After 80 hours, the macerates of each plant were filtered in separate flasks using a qualitative filter paper (what man 44). The residues after filtration process were discarded while the filtrate parts were taken to a vacuum rotary evaporator (RE$52 \mathrm{~A}, 220 \mathrm{~V} / 50 \mathrm{~Hz}$ ) machine for extraction with $35-40^{\circ} \mathrm{C}$ temperature adjustment. The methanol and chloroform crude extract products were poured into evaporating dishes and kept in dry oven (DHG-9030) at $40^{\circ} \mathrm{C}$ for 3-4 days until the extract materials were concentrated. Finally, the percentage yield of each plant extract was calculated (Table 2).

2.2. Agar Well Diffusion and MICs. Media preparation and agar well diffusion assay were done as previously described [46]. The American Type Culture Collection of Staphylococcus aureus 25923, Pseudomonas aeruginosa 27853, and Escherichia coli 20922 were obtained from the Ethiopian public health institute and were maintained on Brain Heart Infusion (BHI) agar medium (HiMedia) at $4^{\circ} \mathrm{C}$ until the commencement of the experiment. The test suspension was standardized to match $0.5 \mathrm{McF}$ arland turbidity standard which corresponds to approximately $1.5 \times 10^{8} \mathrm{CFU} / \mathrm{ml}$. A working solution $(50 \mu \mathrm{g} / \mathrm{ml})$ of streptomycin (mM EDTA, analytical standard) was prepared from stock solution as a positive control, and 5\% DiMethyl Sulphoxide (DMSO) (ACS reagent grade) was used as a negative control.

Three concentrations, 200, 100, and $50 \mathrm{mg} / \mathrm{ml}$, of 5 crude plant extracts were used as a test material. Standardized inocula were swabbed uniformly onto solidified Mueller Hinton agar and the seeded media were allowed to dry for about 5 minutes. Five wells per plate (three wells for extracts, one for each of the positive and negative control) were made in the seeded agar using $6 \mathrm{~mm}$ cork borer. With the help of micropipette, $20 \mu \mathrm{l}$ of test solution was poured into the respective wells. The media were kept in the biosafety for $1 \mathrm{hr}$ for proper diffusion and thereafter incubated at $37^{\circ} \mathrm{C}$ for $24 \mathrm{hrs}$. The experiment was repeated three times and the results, zones of inhibition of each dose, were expressed as the mean of the replicates.

The MIC was evaluated using agar dilution method [46], and MHA culture media were used. Serial dilutions of the plant extracts were prepared by dissolving in 5\% DMSO to make concentrations of $15.625-1000 \mu \mathrm{g} / \mathrm{ml}$. Two $\mathrm{ml}$ aliquot of the plant extract dilution of each concentration to be tested was added to $19 \mathrm{ml}$ of the molten agar. The test was performed in triplicate.

2.3. Data Management. Data were entered into Microsoft Excel, 2010, and were transformed using the square root to maintain the normal distribution among the harvested data. Data analysis was performed using JMP statistical software, version 5 (USA, 2002). The model employed was 


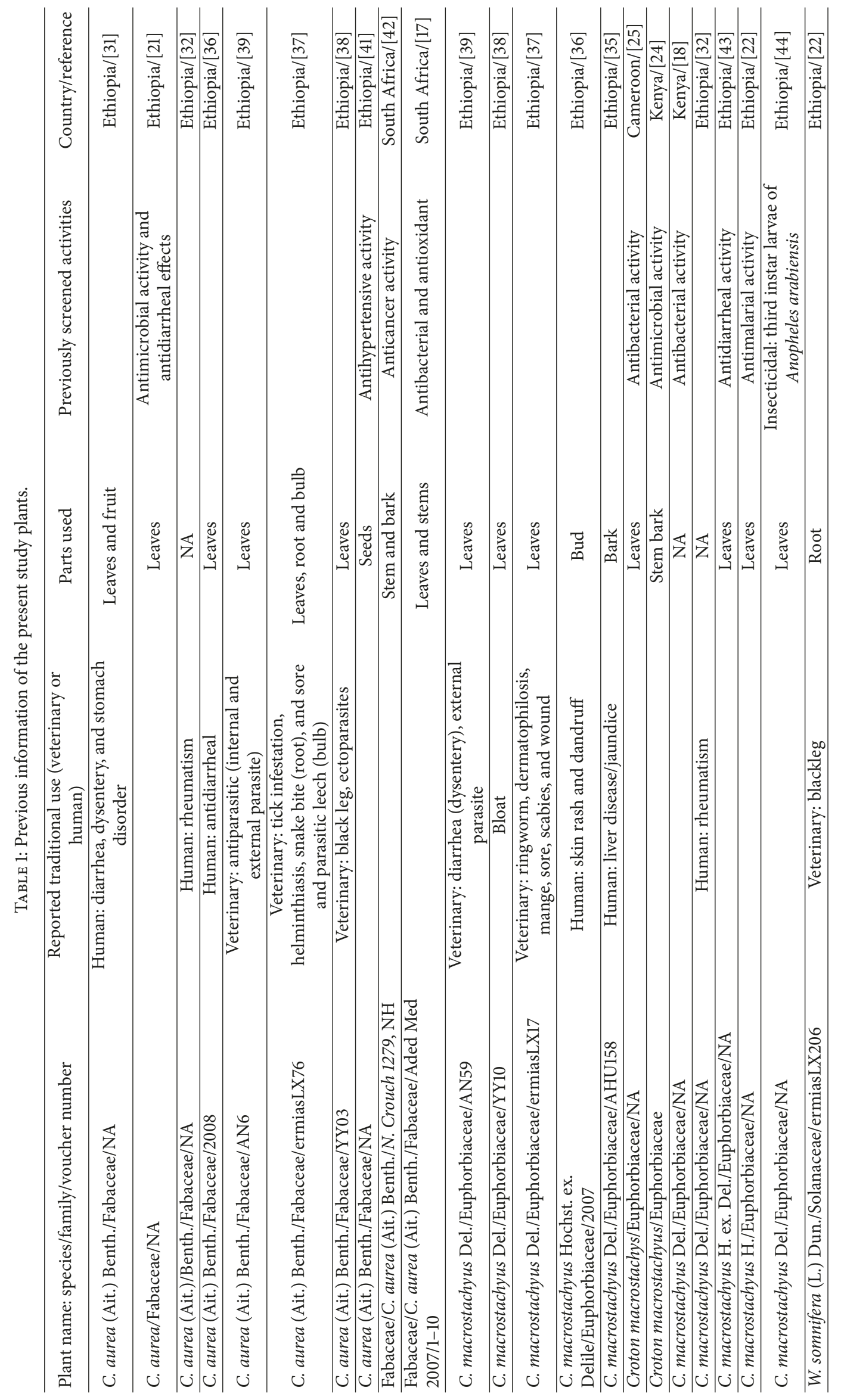




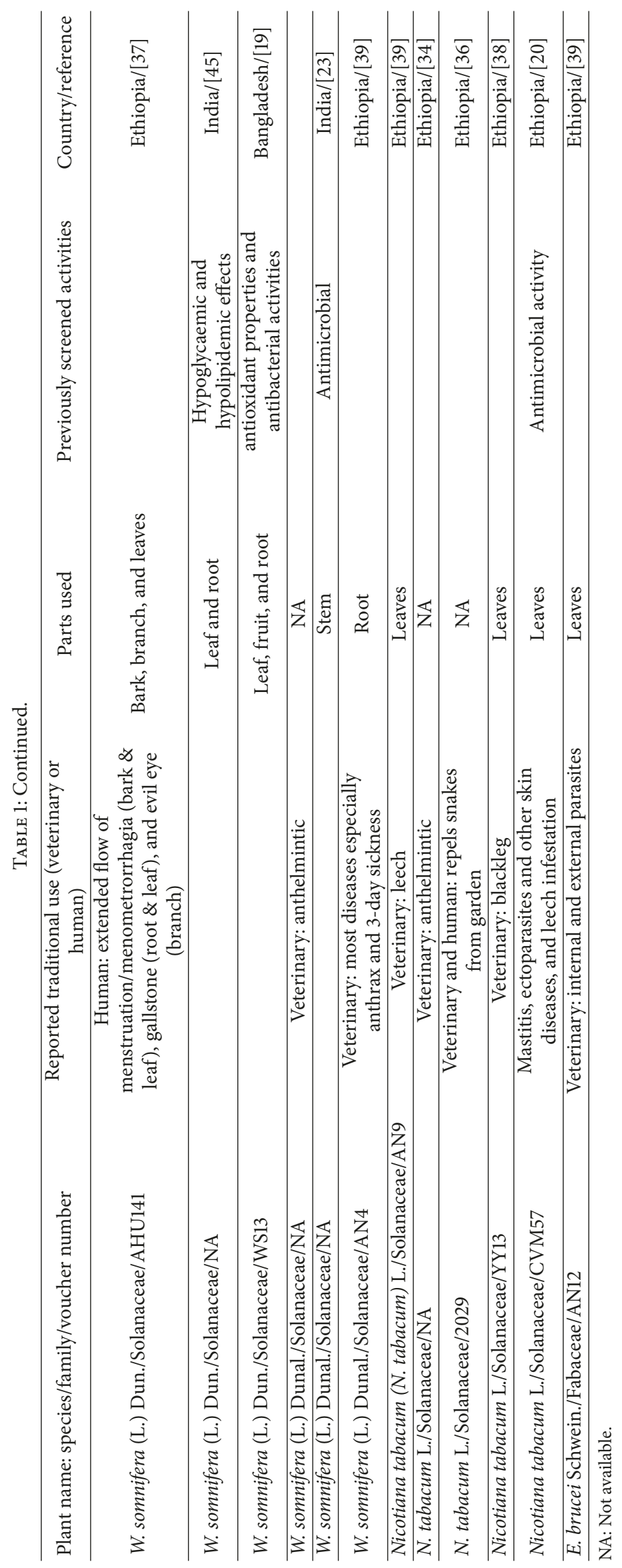


TABLE 2: Percentage yields of plant extracts using methanol and chloroform.

\begin{tabular}{|c|c|c|c|c|c|}
\hline Plant species & Solvent & Plant part used & Weight of sample (g) & Dry weight of extract $(\mathrm{g})$ & Yield (\%) \\
\hline \multirow{2}{*}{ C. macrostachyus Del. } & Methanol & Leaf & 100 & 16.16 & $16.16 \%$ \\
\hline & Chloroform & Leaf & 100 & 18.33 & $18.33 \%$ \\
\hline \multirow{2}{*}{ C. aurea (Ait.) Benth. } & Methanol & Leaf & 100 & 17.33 & $17.33 \%$ \\
\hline & Chloroform & Leaf & 100 & 10 & $10 \%$ \\
\hline \multirow{2}{*}{ W. somnifera (L.) Dunal } & Methanol & Root & 100 & 14.16 & $14.16 \%$ \\
\hline & Chloroform & Root & 100 & 21.3 & $21.3 \%$ \\
\hline \multirow{2}{*}{ E. brucei Schwein. } & Methanol & Leaf & 100 & 11.6 & $11.6 \%$ \\
\hline & Chloroform & Leaf & 100 & 16.66 & $16.66 \%$ \\
\hline \multirow{2}{*}{ N. tabacum L. } & Methanol & Leaf & 100 & 9.3 & $9.3 \%$ \\
\hline & Chloroform & Leaf & 100 & 13.3 & $13.3 \%$ \\
\hline
\end{tabular}

full-factorial ANOVA and expressed with the equation stated below.

$$
y=\mu+a+b+c+a b+a c+b c+a b c+\varepsilon,
$$

where $y$ represents the overall response; $a, b$, and $c$ stand for plant species, dose, and bacterial species, respectively, while $\mu$ and $\varepsilon$ represent overall mean and common error, respectively. $a b, a c, b c$, and $a b c$ indicate the interaction effects of the respective variables. Zone of inhibitions were expressed as mean. Whenever significant variation was detected among treatments, means were separated using Tukey HSD at 5\% level of significance.

\section{Results}

3.1. Percentage Yield of Plant Extracts. Five medicinal plants prioritized by Romha et al. [39] based on their preference by local healers for treating animal and human diseases were collected and extracted (see Materials and Methods) using two solvents: methanol and chloroform. The highest (21.3\%) and lowest $(9.3 \%)$ yields were harvested from chloroform extracts of $W$. somnifera (L.) Dunal and methanol extracts of N. tabacum L., respectively (Table 2 ).

3.2. Antibacterial Activities of Plant Extracts. The methanol and chloroform extracts of the plant species listed in Table 2 were tested using different concentrations (50, 100, and $200 \mathrm{mg} / \mathrm{ml}$ ) against three multidrug resistant bacterial species: S. aureus, $P$. aeruginosa, and E. coli. Of all the plants tested, C. aurea (Ait.) Benth. showed a wide spectrum of antibacterial activities against the investigated bacterial species. Regarding the dosage and solvents, $200 \mathrm{mg} / \mathrm{ml}$ showed best antibacterial activities both in solvents and in all plant species. Better antibacterial activities with maximum zone of inhibition $(4.66 \mathrm{~mm})$ in C. aurea (Ait.) Benth. were recorded in methanol crude extracts at a concentration of $200 \mathrm{mg} / \mathrm{ml}$ against $S$. aureus followed by C. macrostachyus Del. $(4.43 \mathrm{~mm})$ at the same dose and solvent for the same bacterial species (Table 3 ).

Moreover, good results were observed from methanol and chloroform extracts of C. macrostachyus Del. against P. aeruginosa, E. coli, and S. aureus at a concentration of $200 \mathrm{mg} / \mathrm{ml}$.
Methanol extracts of W. somnifera (L.) Dunal showed comparable effect on these bacterial species at the same dose. Methanol and chloroform extracts of E. brucei Schwein. did not inhibit the growth of any bacterial species (Tables 3 and 4). The MIC for crude extracts of each plant for the respective test bacterium was done using the agar dilution method. The lowest value $(62.5 \mu \mathrm{g} / \mathrm{ml})$ of MIC was recorded from both methanol and chloroform extracts of C. aurea (Ait.) Benth. against all the test bacteria. For C. macrostachyus Del., $W$. somnifera (L.) Dunal, and N. tabacum L., the MICs were between $250 \mu \mathrm{g} / \mathrm{ml}$ and $1000 \mu \mathrm{g} / \mathrm{ml}$ in all the test bacteria in both extractants. E. brucei Schwein. did not inhibit the growth of all bacteria employed in this study.

\section{Discussion}

\subsection{The In Vitro Efficacy of Plant Extracts}

4.1.1. Calpurnia aurea (Ait.) Benth. The selected medicinal plant species (Table 2) commonly reported by local healers [39] were evaluated for their efficacy in vitro against three bacteria species: S. aureus, P. aeruginosa, and E. coli. Different zones of inhibition were recorded from each plant extract and from different concentrations for each species of bacterium. The highest zones of inhibition $(4.66 \mathrm{~mm})$ were observed from C. aurea (Ait.) Benth. at concentration of $200 \mathrm{mg} / \mathrm{ml}$ against $S$. aureus from methanol extract which had no statistically significant difference $(P>0.05)$ when compared with the positive control. Consistent with the present study, comparable zones of inhibition with the positive control were reported from methanol extracts of $C$. aurea against $S$. aureus, P. aeruginosa, and E. coli in South Africa [17]. Promising antibacterial activities of methanol extracts of $C$. aurea on these bacterial species have been reported in Ethiopia [21]. Antihypertensive [41], antioxidant [17], and antiparasitic [47] activities of $C$. aurea have also been reported.

4.1.2. Croton macrostachyus Del. Promising antibacterial activities were obtained from methanol and chloroform leaf extracts of Croton macrostachyus Del. against the test bacteria at a concentration of $200 \mathrm{mg} / \mathrm{ml}$. The best activity, even more than the positive control, has been reported from methanol extract of C. macrostachyus against $S$. aureus in 
TABLE 3: The antibacterial activity of methanol extracts of five medicinal plants zone of inhibition in diameter $(\mathrm{mm})$.

\begin{tabular}{|c|c|c|c|c|}
\hline \multirow{2}{*}{ Plant species used } & \multirow{2}{*}{ Concentration $(\mathrm{mg} / \mathrm{ml})$} & \multicolumn{3}{|c|}{ Mean zone of inhibition in diameter $(\mathrm{mm})$} \\
\hline & & S. aureus & E. coli & P. aeruginosa \\
\hline \multirow{3}{*}{ C. aurea (Ait.) Benth. } & 200 & $4.66^{\mathrm{a}, \mathrm{b}}$ & $4.03^{\mathrm{d}-\mathrm{f}}$ & $4.4^{\mathrm{b}-\mathrm{d}}$ \\
\hline & 100 & $3.66^{\mathrm{f}, \mathrm{g}}$ & $3.3^{\mathrm{g}-\mathrm{i}}$ & $3.43^{\mathrm{g}, \mathrm{h}}$ \\
\hline & 50 & $2.53^{1, \mathrm{~m}}$ & $2.66^{\mathrm{k}-\mathrm{m}}$ & $2.8^{\mathrm{j}-1}$ \\
\hline \multirow{3}{*}{ C. macrostachyus Del. } & 200 & $4.43^{\mathrm{b}, \mathrm{c}}$ & $4.13^{\mathrm{c}-\mathrm{e}}$ & $4.2^{\mathrm{c}, \mathrm{d}, \mathrm{e}}$ \\
\hline & 100 & $2.86^{\mathrm{j}-1}$ & $3.0^{\mathrm{i}-\mathrm{k}}$ & $2.86^{\mathrm{j}-1}$ \\
\hline & 50 & $2.0^{\mathrm{o}, \mathrm{p}}$ & $1.8^{\mathrm{p}, \mathrm{q}}$ & $2.33^{\mathrm{m}-\mathrm{o}}$ \\
\hline \multirow{3}{*}{ W. somnifera (L.) Dunal } & 200 & $3.96^{\mathrm{e}, \mathrm{f}}$ & $4.03^{\mathrm{d}-\mathrm{f}}$ & $4.26^{\mathrm{c}-\mathrm{e}}$ \\
\hline & 100 & $2.4^{\mathrm{m}, \mathrm{n}}$ & $2.06^{\mathrm{n}-\mathrm{p}}$ & $2.33^{\mathrm{m}-\mathrm{o}}$ \\
\hline & 50 & $1.7^{\mathrm{p}, \mathrm{q}}$ & $1.7^{\mathrm{p}, \mathrm{q}}$ & $1.7^{\mathrm{p}, \mathrm{q}}$ \\
\hline \multirow{3}{*}{ N. tabacum L. } & 200 & $3.1^{\mathrm{h}-\mathrm{j}}$ & $3.33^{g-i}$ & $2.53^{1, \mathrm{~m}}$ \\
\hline & 100 & $2.86^{\mathrm{j}-1}$ & $2.8^{\mathrm{j}-1}$ & $2.86^{\mathrm{j}-1}$ \\
\hline & 50 & $1.8^{\mathrm{p}, \mathrm{q}}$ & $1.7^{\mathrm{p}, \mathrm{q}}$ & $1.6^{\mathrm{q}}$ \\
\hline \multirow{3}{*}{ E. brucei Schwein. } & 200 & $0^{\mathrm{r}}$ & $0^{\mathrm{r}}$ & $0^{\mathrm{r}}$ \\
\hline & 100 & $0^{\mathrm{r}}$ & $0^{\mathrm{r}}$ & $0^{\mathrm{r}}$ \\
\hline & 50 & $0^{\mathrm{r}}$ & $0^{\mathrm{r}}$ & $0^{\mathrm{r}}$ \\
\hline \multirow{3}{*}{ Streptomycin } & 200 & $4.9^{\mathrm{a}}$ & $4.9^{\mathrm{a}}$ & $4.9^{\mathrm{a}}$ \\
\hline & 100 & $4.9^{\mathrm{a}}$ & $4.9^{\mathrm{a}}$ & $4.9^{\mathrm{a}}$ \\
\hline & 50 & $4.9^{\mathrm{a}}$ & $4.9^{\mathrm{a}}$ & $4.9^{\mathrm{a}}$ \\
\hline \multirow{3}{*}{ DMSO } & 200 & $0^{\mathrm{r}}$ & $0^{\mathrm{r}}$ & $0^{\mathrm{r}}$ \\
\hline & 100 & $0^{\mathrm{r}}$ & $0^{\mathrm{r}}$ & $0^{\mathrm{r}}$ \\
\hline & 50 & $0^{\mathrm{r}}$ & $0^{\mathrm{r}}$ & $0^{\mathrm{r}}$ \\
\hline
\end{tabular}

NB: levels not connected by the same letter are significantly different.

a previous study conducted in Ethiopia [20]. The methanol extracts of C. macrostachyus Del. also showed a potential antibacterial activity against $E$. coli and P. aeruginosa [18]. An interesting activity has been recorded from methanol extracts of leaf C. macrostachyus against wide range of Grampositive and Gram-negative bacterial species including $S$. aureus, P. aeruginosa, and E. coli [25]. Moderate antibacterial activity result has also been recorded from stem bark extract of C. macrostachyus [24]. In fact, antibacterial secondary metabolites such as polyphenols, triterpenes, and saponins were isolated from the leaf of this plant [25]. Moreover, antimalarial [22] and insecticidal [44] activities of leaf extracts of this plant have also been reported in Ethiopia.

4.1.3. Withania somnifera (L.) Dunal. Though W. somnifera (L.) Dunal has been used by the Ethiopian local healers for the treatment of different animal and human ailments [34-37, 39], scientific data on its antimicrobial activity is inadequate. Methanol extract of $W$. somnifera (L.) Dunal (root) revealed a promising antimicrobial activity against the test bacteria while chloroform extract of the plant showed moderate activity. W. somnifera is widely used as traditional medicine in Pakistan and strong antibacterial activities have been reported from methanol extract of $W$. somnifera (leaf) in the same country as reviewed in Adnan et al. [48]. High and moderate antibacterial activities have been recorded for methanol extract of $W$. somnifera (L.) Dunal stem against E. coli and P. aeruginosa, respectively, in
India [23]. Leaves, fruits, and roots of $W$. somnifera showed the same antibacterial activities against these two bacterial species and the highest activities were recorded from the plants' leaves [19]. W. somnifera also exhibited antioxidant [19] and anti-inflammatory [49] properties.

4.1.4. Nicotiana tabacum L. and Erythrina brucei Schwein. Weak antimicrobial activities were observed from methanol and chloroform extracts of $N$. tabacum L. against all the test bacteria. Moreover, E. brucei Schwein. did not totally inhibit the bacterial growth in the present study. However, good antimicrobial activities from methanol extract of $N$. tabacum L. have been reported from a previous study [20]. The difference in its medicinal value may possibly be risen due to agroecological difference. The use of these plants as a traditional medicine to treat various diseases of humans and animals is commonly reported in Ethiopia [20, 33, 36, 38, 39] and in Pakistan [50]. E. brucei Schwein. did not inhibit the bacterial growth in all concentrations. The plant might be active against parasites which supports the traditional belief documented previously [39]. However, this is preliminary evidence and needs further researches. Additional researches on antimicrobial activities as well as their phytochemical analysis of these plants should be conducted.

4.2. Sensitivity of the Test Bacteria to the Extracts. The highest zone of inhibition was recorded in the crude extract tested against $S$. aureus. Previous experimental works showed 
TABLE 4: The antibacterial activity of chloroform extracts of five medicinal plants zone of inhibition in diameter ( $\mathrm{mm}$ ).

\begin{tabular}{|c|c|c|c|c|}
\hline \multirow{2}{*}{ Plant species used } & \multirow{2}{*}{ Concentration $(\mathrm{mg} / \mathrm{ml})$} & \multicolumn{3}{|c|}{ Mean zone of inhibition in diameter $(\mathrm{mm})$} \\
\hline & & S. aureus & E. coli & P. aeruginosa \\
\hline \multirow{3}{*}{ C. aurea (Ait.) Benth. } & 200 & $3.96^{\mathrm{b}-\mathrm{d}}$ & $4.0^{\mathrm{b}, \mathrm{c}}$ & $4.26^{\mathrm{b}}$ \\
\hline & 100 & $3.5^{\mathrm{f}}$ & $2.33^{1-p}$ & $3.53^{\mathrm{e}, \mathrm{f}}$ \\
\hline & 50 & $2.2^{\mathrm{n}-\mathrm{r}}$ & $2.26^{\mathrm{m}-\mathrm{q}}$ & $2.4^{\mathrm{k}-\mathrm{p}}$ \\
\hline \multirow{3}{*}{ C. macrostachyus Del. } & 200 & $3.93^{\mathrm{b}-\mathrm{e}}$ & $3.56^{\mathrm{d}-\mathrm{f}}$ & $3.73^{\mathrm{c}-\mathrm{f}}$ \\
\hline & 100 & $3.0^{\mathrm{g}-\mathrm{i}}$ & $3.0^{\mathrm{g}-\mathrm{i}}$ & $3.03^{\mathrm{g}, \mathrm{h}}$ \\
\hline & 50 & $2.13^{\mathrm{o}-\mathrm{r}}$ & $2.2^{\mathrm{n}-\mathrm{r}}$ & $2.4^{\mathrm{k}-\mathrm{p}}$ \\
\hline \multirow{3}{*}{ W. somnifera (L.) Dunal } & 200 & $3.4^{\mathrm{f}, \mathrm{g}}$ & $3.06^{\mathrm{g}, \mathrm{h}}$ & $2.6^{\mathrm{i}-\mathrm{n}}$ \\
\hline & 100 & $2.86^{\mathrm{h}-\mathrm{j}}$ & $2.26^{\mathrm{m}-\mathrm{q}}$ & $2.4^{\mathrm{k}-\mathrm{p}}$ \\
\hline & 50 & $1.8^{\mathrm{r}, \mathrm{s}}$ & $2.0^{\mathrm{p}-\mathrm{s}}$ & $2.0^{\mathrm{p}-\mathrm{s}}$ \\
\hline \multirow{3}{*}{ N. tabacum L. } & 200 & $2.66^{\mathrm{h}-\mathrm{m}}$ & $2.8^{\mathrm{h}-\mathrm{k}}$ & $2.53^{j-o}$ \\
\hline & 100 & $2.73^{\mathrm{h}-1}$ & $2.46^{j-o}$ & $2.4^{\mathrm{k}-\mathrm{p}}$ \\
\hline & 50 & $1.6^{\mathrm{s}}$ & $1.8^{\mathrm{r}, \mathrm{s}}$ & $1.9^{\mathrm{q}-\mathrm{s}}$ \\
\hline \multirow{3}{*}{ E. brucei Schwein. } & 200 & $0^{\mathrm{t}}$ & $0^{t}$ & $0^{\mathrm{t}}$ \\
\hline & 100 & $0^{\mathrm{t}}$ & $0^{\mathrm{t}}$ & $0^{\mathrm{t}}$ \\
\hline & 50 & $0^{\mathrm{t}}$ & $0^{\mathrm{t}}$ & $0^{\mathrm{t}}$ \\
\hline \multirow{3}{*}{ Streptomycin } & 200 & $4.9^{\mathrm{a}}$ & $4.9^{\mathrm{a}}$ & $4.9^{\mathrm{a}}$ \\
\hline & 100 & $4.9^{\mathrm{a}}$ & $4.9^{\mathrm{a}}$ & $4.9^{\mathrm{a}}$ \\
\hline & 50 & $4.9^{\mathrm{a}}$ & $4.9^{\mathrm{a}}$ & $4.9^{\mathrm{a}}$ \\
\hline \multirow{3}{*}{ DMSO } & 200 & $0^{t}$ & $0^{t}$ & $0^{t}$ \\
\hline & 100 & $0^{\mathrm{t}}$ & $0^{\mathrm{t}}$ & $0^{\mathrm{t}}$ \\
\hline & 50 & $0^{t}$ & $0^{t}$ & $0^{t}$ \\
\hline
\end{tabular}

NB: levels not connected by the same letter are significantly different.

that, among a group of bacteria tested for crude extracts of different plant species, $S$. aureus was found sensitive comparably in all plant extracts [20,51-53]. Likewise, considerable studies indicated that extracts from different plant species exhibited better activities on Gram-positive bacteria than on Gram-negative bacteria [54-61], while some studies reported that $P$. aeruginosa $[61,62]$ and E. coli [21] were also sensitive to extracts of some medicinal plants. These sensitivity differences between Gram-positive and Gramnegative bacteria to the extract of different medicinal plants might be due to the structural and compositional differences in membranes between the two groups [63]. Indeed, Gramnegative bacteria are more resistant to antibiotics because they possess impermeable outer membrane; consequently, the levels of antibiotics in the cell are reduced [64].

Previous study indicated that plant extracts with MICs up to $100 \mu \mathrm{g} / \mathrm{ml}$ have significant antibacterial activity. If the MICs of the plant extracts are between 100 and $625 \mu \mathrm{g} / \mathrm{ml}$ and above $625 \mu \mathrm{g} / \mathrm{ml}$, the antibacterial activity of the respective plant extract is considered to be moderate and low, respectively [65]. The present study had its own limitation in that the method we employed for testing the plants' crude extracts was agar well diffusion; thus, nonpolar compounds may not diffuse well into the aqueous agar matrix thereby antibacterial activity of the plants may be underestimated.

\section{Conclusion}

The results of the present study support the traditional uses of these plants practiced by the local healers. Except E. brucei Schwein., all the plants investigated in this study exhibited antibacterial activities against the test bacterial species. However, it was reported that E. brucei Schwein. has been used for the treatment of external and internal parasites [39]. Further researches are needed to be conducted to evaluate the efficacy of these medicinal plant species on other microbes in different agroecological settings and their safety levels as well as their phytochemical compositions.

\section{Additional Points}

Availability of Data and Materials. All data generated during this study are included in this published article. Plant materials used in this study have been identified at the National Herbarium of Addis Ababa University and voucher specimens are deposited at the College of Agriculture and 
Natural Resource, Dilla University. The bacterial strains used for the experiment are available at the Ethiopian public health institute.

\section{Disclosure}

The funding institution had no role in designing the study, data collection, analysis and interpretation of data as well as in writing the manuscript.

\section{Conflicts of Interest}

The authors declare that there are no conflicts of interest regarding the publication of this article.

\section{Authors' Contributions}

Gebremedhin Romha conceived and designed the study; Gebremedhin Romha and Birhanu Admasu collected the plants; Gebremedhin Romha, Birhanu Admasu, Tsegaye Hiwot Gebrekidan, and Hailelule Aleme prepared the plant extracts; Gebremedhin Romha, Birhanu Admasu, Hailelule Aleme, and Gebreyohans Gebru conducted the experiment; Gebremedhin Romha and Gebreyohans Gebru drafted the manuscript; Gebremedhin Romha, Birhanu Admasu, Tsegaye Hiwot Gebrekidan, Hailelule Aleme, and Gebreyohans Gebru read and approved the manuscript.

\section{Acknowledgments}

The authors would like to thank Mr. Kirubel Kassahun and Kaleb Kifle, staff of Dilla University, for their devoted technical support when the experiment was conducted. The study received partial financial support from Dilla University with Grant no. AgNR/AnSc/2015/10.

\section{References}

[1] D. L. Archer and F. E. Young, "Contemporary issues: Diseases with a food vector," Clinical Microbiology Reviews, vol. 1, no. 4, pp. 377-398, 1988.

[2] Institute of Food Technologtiss, Bacteria Associated with Foodborne Diseases, 2004. http://seafood.oregonstate.edu/.pdf\% 20Links/Bacteria-Associated-with-Foodborne-Diseases-Scientific-Status-Summary-Update\%282004\%29-IFT.pdf.

[3] S. G. Machado, F. Baglinière, S. Marchand et al., "The biodiversity of the microbiota producing heat-resistant enzymes responsible for spoilage in processed bovine milk and dairy products," Frontiers in Microbiology, vol. 8, article no. 302, 2017.

[4] G. Stellato, D. R. Utter, A. Voorhis, M. De Angelis, A. Murat Eren, and D. Ercolini, "A few Pseudomonas oligotypes dominate in the meat and dairy processing environment," Frontiers in Microbiology, vol. 8, article no. 264, 2017.

[5] F. D. Lowy, "Antimicrobial resistance: the example of Staphylococcus aureus," The Journal of Clinical Investigation, vol. 111, no. 9, pp. 1265-1273, 2003.

[6] D. A. Tadesse, S. Zhao, and E. Tong, "Antimicrobial drug resistance in Escherichia coli from humans and food animals, United States, 1950-2002," Emerging Infectious Diseases, vol. 18, no. 5, pp. 741-749, 2012.
[7] T. Strateva and D. Yordanov, "Pseudomonas aeruginosa: a phenomenon of bacterial resistance," Journal of Medical Microbiology, vol. 58, no. 9, pp. 1133-1148, 2009.

[8] A.-P. Magiorakos, A. Srinivasan, R. B. Carey et al., "Multidrugresistant, extensively drug-resistant and pandrug-resistant bacteria: an international expert proposal for interim standard definitions for acquired resistance," Clinical Microbiology and Infection, vol. 18, no. 3, pp. 268-281, 2012.

[9] W. Bereket, K. Hemalatha, B. Getenet et al., "Update on bacterial nosocomial infections," European Review for Medical and Pharmacological Sciences, vol. 16, no. 8, pp. 1039-1044, 2012.

[10] National strategy for combating antibiotic - resistant bacteria, 2014, https://www.cdc.gov/drugresistance/pdf/carb_national_ strategy.pdf.

[11] Santos, A. C. X. Oliveira, and T. C. B. Tomassini, "Controle microbiógico de produtos fitoterápicos," Revista De Farmacia E Bioquimica, vol. 31, pp. 35-38, 1995.

[12] S. D. In Dwivedi and S. A. Wagay, "Antimicrobialactivity of leaf extracts of Jurineadolomiaea plant against clinical and phytopathogenic bacteria," Chemical and Process Engineering Research, vol. 24, pp. 9-13, 2014.

[13] R. Pankhurst, An Introduction to the Medical History of Ethiopia, The Red Sea press, New Jersey, NJ, USA, 1965.

[14] R. Pankhurst and A. Waldeyes, An Introduction to the Medical History of Ethiopia, The Red Sea Press, Trenton, NJ, USA, 1990.

[15] D. Abebe and A. Ayehu, Medicinal Plants and Enigmatic Health Practices of Northern Ethiopia, Berhanina Selam Printing Press, Addis Ababa, Ethiopia, 1993.

[16] J. N. Eloff, "Which extractant should be used for the screening and isolation of antimicrobial components from plants?" Journal of Ethnopharmacology, vol. 60, no. 1, pp. 1-8, 1998.

[17] A. A. Adedapo, F. O. Jimoh, S. Koduru, A. J. Afolayan, and P. J. Masika, "Antibacterial and antioxidant properties of the methanol extracts of the leaves and stems of Calpurnia aurea," BMC Complementary and Alternative Medicine, vol. 8, article 53, 2008.

[18] C. G. Wagate, J. M. Mbaria, D. W. Gakuya et al., "Screening of some Kenyan medicinal plants for antibacterial activity," Phytotherapy Research, vol. 24, no. 1, pp. 150-153, 2010.

[19] N. Alam, M. Hossain, M. A. Mottalib, S. A. Sulaiman, S. H. Gan, and M. I. Khalil, "Methanolic extracts of Withania somnifera leaves, fruits and roots possess antioxidant properties and antibacterial activities," BMC Complementary and Alternative Medicine, vol. 12, no. 1, article 175, 2012.

[20] S. Kalayou, M. Haileselassie, G. Gebre-egziabher et al., "Invitro antimicrobial activity screening of some ethnoveterinary medicinal plants traditionally used against mastitis, wound and gastrointestinal tract complication in Tigray Region, Ethiopia," Asian Pacific Journal of Tropical Biomedicine, vol. 2, no. 7, pp. 516-522, 2012.

[21] S. Umer, A. Tekewe, and N. Kebede, "Antidiarrhoeal and antimicrobial activity of Calpurnia aurea leaf extract," BMC Complementary and Alternative Medicine, vol. 13, article 21, 2013.

[22] L. Bantie, S. Assefa, T. Teklehaimanot, and E. Engidawork, "In vivo antimalarial activity of the crude leaf extract and solvent fractions of Croton macrostachyus Hocsht. (Euphorbiaceae) against Plasmodium berghei in mice," BMC Complementary and Alternative Medicine, vol. 14, article 79, 2014.

[23] D. Dharajiya, P. Patel, M. Patel, and N. Moitra, "In vitro antimicrobial activity and qualitative phytochemical analysis of Withania somnifera (L.) dunal extracts," International Journal 
of Pharmaceutical Sciences Review and Research, vol. 27, no. 2, pp. 349-354, 2014.

[24] J. K. Obey, A. von Wright, J. Orjala, J. Kauhanen, and C. Tikkanen-Kaukanen, "Antimicrobial activity of Croton macrostachyus stem bark extracts against several human pathogenic bacteria," Journal of Pathogens, vol. 2016, Article ID 1453428, 5 pages, 2016.

[25] I. K. Voukeng, V. P. Beng, and V. Kuete, "Antibacterial activity of six medicinal Cameroonian plants against Gram-positive and Gram-negative multidrug resistant phenotypes," BMC Complementary and Alternative Medicine, vol. 16, no. 1, article no. 388, 2016.

[26] G. Ren, L. Li, H. Hu, Y. Li, C. Liu, and S. Wei, "Influence of the environmental factors on the accumulation of the bioactive ingredients in Chinese rhubarb products," PLOS ONE, vol. 11, no. 5, article e0154649, 2016.

[27] C. Mahidol, S. Ruchirawat, H. Prawat et al., "Biodiversity and natural product drug discovery," Pure and Applied Chemistry, vol. 70, no. 11, pp. 2065-2072, 1998.

[28] S. B. Lee, K. H. Cha, and S. N. Kim, "Theantimicrobial activity of essential oil from Dracocephalum foetidum against pathogenic Microorganisms," Journal of Microbiology, vol. 45, pp. 45-53, 2007.

[29] M. Lahlou, "Screening of natural products for drug discovery," Expert Opinion on Drug Discovery, vol. 2, no. 5, pp. 697-705, 2007.

[30] T. Sori, M. Bekana, G. Adunga et al., "Medicinal plants in ethnoveterinary practices of borana pastoralists," International Journal of Appllied Research and Veterinary Medicine, vol. 2, pp. 220-225, 2004.

[31] T. Teklehaymanot and M. Giday, "Ethnobotanical study of medicinal plants used by people in Zegie Peninsula, Northwestern Ethiopia," Journal of Ethnobiology and Ethnomedicine, vol. 3, article 12, 2007.

[32] H. Yineger, D. Yewhalaw, and D. Teketay, "Ethnomedicinal plant knowledge and practice of the Oromo ethnic group in southwestern Ethiopia," Journal of Ethnobiology and Ethnomedicine, vol. 4, article no. 11, 2008.

[33] F. Mesfin, S. Demissew, and T. Teklehaymanot, "An ethnobotanical study of medicinal plants in Wonago Woreda, SNNPR, Ethiopia," Journal of Ethnobiology and Ethnomedicine, vol. 5, no. $28,2009$.

[34] C. E. Scantlebury, L. Peachey, J. Hodgkinson et al., "Participatory study of medicinal plants used in the control of gastrointestinal parasites in donkeys in Eastern Shewa and Arsi zones of Oromia region, Ethiopia," BMC Veterinary Research, vol. 9, article no. 179, 2013.

[35] A. Belayneh and N. F. Bussa, "Ethnomedicinal plants used to treat human ailments in the prehistoric place of Harla and Dengego valleys, eastern Ethiopia," Journal of Ethnobiology and Ethnomedicine, vol. 10, article 18, 2014.

[36] E. d'Avigdor, H. Wohlmuth, Z. Asfaw, and T. Awas, "The current status of knowledge of herbal medicine and medicinal plants in Fiche, Ethiopia," Journal of Ethnobiology and Ethnomedicine, vol. 10, no. 1, pp. 38-71, 2014.

[37] E. Lulekal, Z. Asfaw, E. Kelbessa, and P. Van Damme, "Ethnoveterinary plants of Ankober District, North Shewa Zone, Amhara Region, Ethiopia," Journal of Ethnobiology and Ethnomedicine, vol. 10, no. 1, article no. 21, 2014.

[38] Y. Yigezu, D. B. Haile, and W. Y. Ayen, "Ethnoveterinary medicines in four districts of jimma zone, Ethiopia: cross sectional survey for plant species and mode of use," BMC Veterinary Research, vol. 10, article 76, 2014.

[39] G. Romha, T. A. Dejene, L. B. Telila, and D. F. Bekele, "Ethnoveterinary medicinal plants: preparation and application methods by traditional healers in selected districts of southern Ethiopia," Veterinary World, vol. 8, no. 5, pp. 674-684, 2015.

[40] G. G. F. Nascimento, J. Locatelli, P. C. Freitas, and G. L. Silva, "Antibacterial activity of plant extracts and phytochemicals on antibiotic-resistant bacteria," Brazilian Journal of Microbiology, vol. 31, no. 4, pp. 247-256, 2000.

[41] Y. Getiye, T. Tolessa, and E. Engidawork, "Antihypertensive activity of $80 \%$ methanol seed extract of Calpurnia aurea (Ait.) Benth. subsp. aurea (Fabaceae) is mediated through calcium antagonism induced vasodilation," Journal of Ethnopharmacology, vol. 189, pp. 99-106, 2016.

[42] E. Korir, J. J. Kiplimo, N. R. Crouch, N. Moodley, and N. A. Koorbanally, "Isoflavones from Calpurnia aurea subsp. aurea and their anticancer activity," African Journal of Traditional, Complementary and Alternative Medicines, vol. 11, no. 5, pp. 3337, 2014.

[43] A. Degu, E. Engidawork, and W. Shibeshi, "Evaluation of the anti-diarrheal activity of the leaf extract of Croton macrostachyus Hocsht. ex Del. (Euphorbiaceae) in mice model," $B M C$ Complementary and Alternative Medicine, vol. 16, article 379, 2016.

[44] K. Karunamoorthi and K. Ilango, "Larvicidal activity of Cymbopogon citratus (DC) Stapf. and Croton macrostachyus Del. against Anopheles arabiensis Patton, a potent malaria vector," European Review for Medical and Pharmacological Sciences, vol. 14, pp. 57-62, 2010.

[45] R. Udayakumar, S. Kasthurirengan, T. S. Mariashibu et al., "Hypoglycaemic and hypolipidaemic effects of withania somnifera root and leaf extracts on alloxan-induced diabetic rats," International Journal of Molecular Sciences, vol. 10, no. 5, pp. 2367-2382, 2009.

[46] CLSI, Performance Standards for Antimicrobial Susceptibility Testing: Twenty-Second Informational Supplement, 2012.

[47] N. Gemeda, W. Mokonnen, H. Lemma et al., "Insecticidal activity of some traditionally used Ethiopian medicinal plants against sheep ked Melophagus ovinus," Journal of Parasitology Research, vol. 2014, Article ID 978537, 7 pages, 2014.

[48] M. Adnan, R. Bibi, S. Mussarat, A. Tariq, and Z. K. Shinwari, "Ethnomedicinal and phytochemical review of Pakistani medicinal plants used as antibacterial agents against Escherichia coli," Annals of Clinical Microbiology and Antimicrobials, vol. 13, no. 1, article 40, 2014.

[49] E. A. Mazzio, N. Li, D. Bauer et al., "Natural product HTP screening for antibacterial (E.coli 0157:H7) and anti-inflammatory agents in (LPS from E. coli O111:B4) activated macrophages and microglial cells; focus on sepsis," BMC Complementary and Alternative Medicine, vol. 16, no. 1, article no. 467, 2016.

[50] H. Ul Hassan, W. Murad, A. Tariq, and A. Ahmad, "Ethnoveterinary study of medicinal plants in Malakand Valley, District Dir (Lower), Khyber Pakhtunkhwa, Pakistan," Irish Veterinary Journal, vol. 67, no. 1, article 6, 2014.

[51] P. I. Ushimaru, M. T. N. Da Silva, L. C. Di Stasi, L. Barbosa, and A. Fernandes Jr., "Antibacterial activity of medicinal plant extracts," Brazilian Journal of Microbiology, vol. 38, no. 4, pp. 717-719, 2007. 
[52] C. H. Wendakoon, P. Calderon, and D. Gagnon, "Evaluation of selected medicinal plants extracted indifferent ethanol concentrations for antibacterial activity against human pathogens," Journal of Medicinally Active Plants, vol. 1, no. 2, pp. 60-68, 2012.

[53] Y. Mengiste, F. Hagos, F. Moges et al., "In vitro antibacterial screening of extracts from selected Ethiopian medicinal plants," Momona Ethiopian Journal of Science, vol. 6, no. 1, pp. 102-110, 2014.

[54] D. S. Grierson and A. J. Afolayan, "Antibacterial activity of some indigenous plants used for the treatment of wounds in the Eastern Cape, South Africa," Journal of Ethnopharmacology, vol. 66, no. 1, pp. 103-106, 1999.

[55] A. J. Afolayan, "Extracts from the shoots of Arctotis arctotoides inhibit the growth of bacteria and fungi," Pharmaceutical Bio$\log y$, vol. 41, no. 1, pp. 22-25, 2003.

[56] R. Nair and S. Chanda, "In-vitro antimicrobial activity of Psidium guajava L. leaf extracts against clinically important pathogenic microbial strains," Brazilian Journal of Microbiology, vol. 38, no. 3, pp. 452-458, 2007.

[57] R. Nair and S. V. Chanda, "Antibacterial activities of some medicinal plants of the western region of India," Turkish Journal of Biology, vol. 31, no. 4, pp. 231-236, 2007.

[58] M. J. Yaghoubi, G. Ghorbani, S. Soleimanian Zad, and R. Satari, "Antimicrobial activity of Iranian propolis and its chemical composition," DARU Journal of Pharmaceutical Sciences, vol. 15, no. 1, pp. 45-48, 2007.

[59] H. Türker, A. B. Yildirim, and P. F. Arakas, "Antibacterial activities of extracts from some Turkish endemic plants on common fish pathogens," Turkish Journal of Biology, vol. 33, pp. 73-78, 2009.

[60] H. Turker, A. B. Yıldırım, and F. P. Karakaş, "Sensitivity of bacteria isolated from fish to some medicinal plants," Turkish Journal of Fisheries and Aquatic Sciences, vol. 9, no. 2, pp. 181186, 2009.

[61] F. P. Karakaş, A. Yildirim, and A. Türker, "Biological screening of various medicinal plant extracts for antibacterial and antitumor activities," Turkish Journal of Biology, vol. 36, no. 6, pp. 641-652, 2012.

[62] E. Omer, "Antibacterial and antifungal activity of ethanolic extracts from eleven spice plants," Biologia E, vol. 61, no. 3, pp. 275-278, 2006.

[63] P. Lambert, "Cellular impermeability and uptake of biocides and antibiotics in Gram-positive bacteria and mycobacteria," Journal of Applied Microbiology, vol. 92, pp. 46S-54S, 2002.

[64] K. Bockstael and A. Van Aerschot, "Antimicrobial resistance in bacteria," Central European Journal of Medicine, vol. 4, no. 2, pp. 141-155, 2009.

[65] V. Kuete, "Potential of Cameroonian plants and derived products against microbial infections: A review," Planta Medica, vol. 76, no. 14, pp. 1479-1491, 2010. 


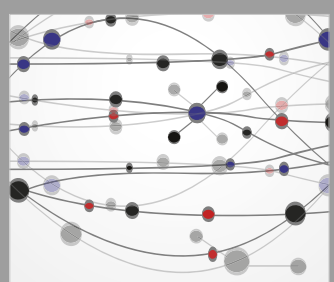

The Scientific World Journal
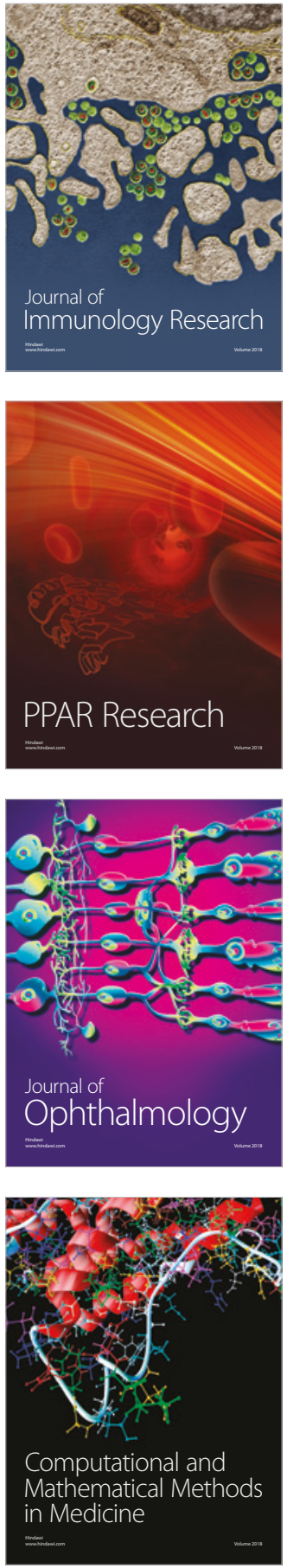

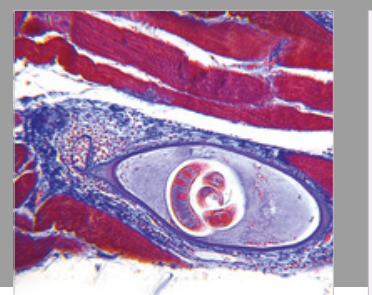

Gastroenterology Research and Practice

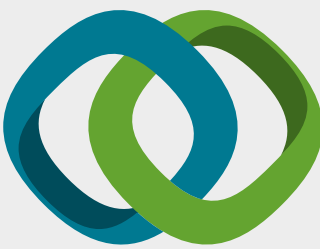

\section{Hindawi}

Submit your manuscripts at

www.hindawi.com
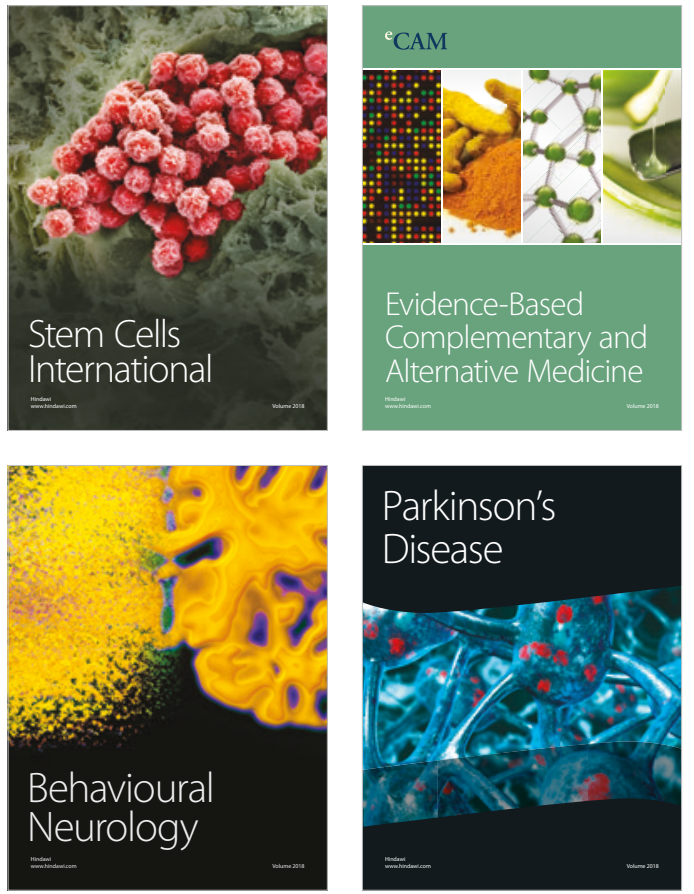

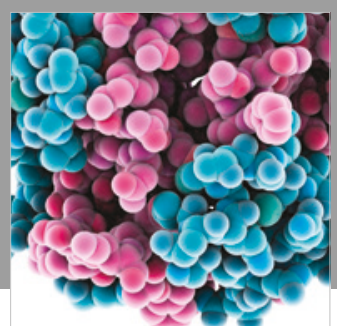

ournal of

Diabetes Research

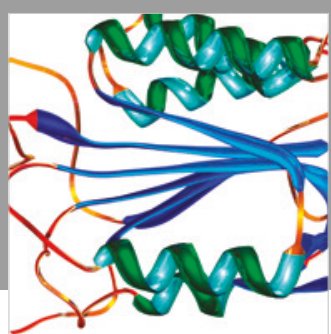

Disease Markers
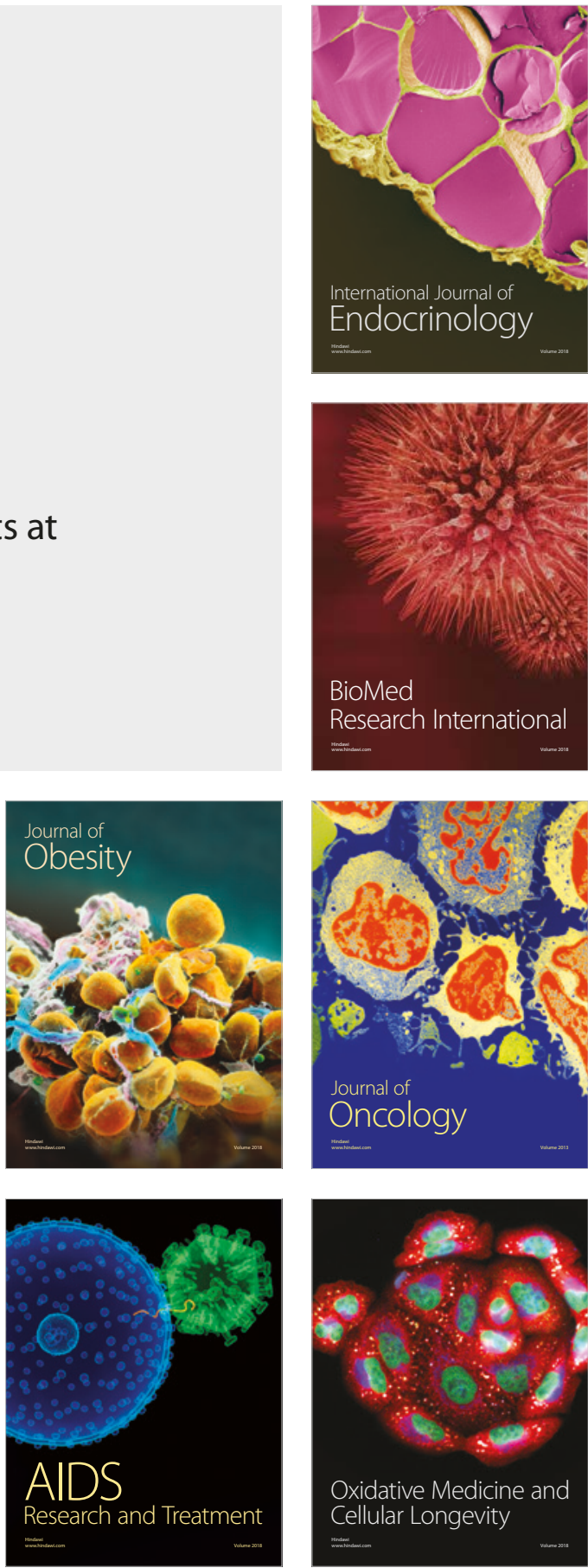